\title{
OCCURRENCE OF ORD'S KANGAROO RAT (DIPODOMYS ORDII) ALONG ITS EASTERN DISTRIBUTIONAL LIMIT IN NEBRASKA
}

\author{
Greg D. Wright ${ }^{1,2}$ and Keith Geluso ${ }^{1}$
}

\begin{abstract}
Changes in land use continue to alter habitats throughout Nebraska, and few studies have examined how such changes affect distributional limits of mammals. The distribution of Ord's kangaroo rat (Dipodomys ordii) was last examined in eastern Nebraska about 4 decades ago. We examined the current eastern distributional limits of $D$. ordii to see whether its range had expanded, contracted, or remained constant in the state since the 1960s. Based on our study, kangaroo rats have experienced little change in distribution during recent decades. Herein, we report on data for 8 counties without prior records and a marginal range extension, as well as comment on habitat, reproduction, and taxonomic status of kangaroo rats in eastern Nebraska.
\end{abstract}

REsumen.-Los cambios en el uso del suelo siguen modificando los hábitats a lo largo del estado de Nebraska, y pocos estudios han examinado cómo estos cambios afectan los límites de distribución de los mamíferos. La última evaluación de la distribución de la rata canguro de Ord (Dipodomys ordii) en el este de Nebraska se llevó a cabo hace 4 décadas. Examinamos los límites orientales actuales de la distribución de $D$. ordii para ver si su área de distribución se ha expandido, contraído o permanecido igual en el estado desde los años 1960. Con base en nuestra investigación, es posible decir que la distribución de las ratas canguro ha cambiado poco en décadas recientes. Aquí reportamos datos para 8 condados para los cuales no existían registros anteriores e informamos sobre una pequeña expansión de su área de distribución. También comentamos sobre el hábitat, la reproducción y la situación taxonómica de las ratas canguro en el este de Nebraska.

Mammalian distributions are continually changing in response to climate and habitat; however, distributions of species depicted on maps are generally static, representing an accumulation of records from many decades (Rapoport 1982, Hafner and Schuster 1996). Documentation of extralimital populations can represent natural expansions due to changing environmental conditions or can represent discovery of previously overlooked populations (Hafner and Schuster 1996, Frey 2009). Some expansions also may represent recolonization of former areas of occurrence by the continual ebb and flow of distributional limits along their perimeters. During the past 40 years in Nebraska, many mammalian species have expanded their distributional limits while only a few have had contracting ranges (Benedict et al. 2000). For species with range expansions, most have shifted westward, northward, and southward, whereas only 5 species have shifted eastward (Benedict et al. 2000). Species with contracting ranges in Nebraska generally are habitat specialists affected by habitat degradation and fragmentation.

The objective of our study was to examine the current eastern distributional limits of Ord's kangaroo rat (Dipodomys ordii) in Nebraska. This species has been documented across much of the western two-thirds of the state, with its easternmost limits forming a line from Knox County to Platte County and from Platte County to Webster County (Jones 1964). We were unaware of any recent records along its easternmost limits, and we investigated whether its range had expanded, contracted, or remained constant since the last published distribution for D. ordii in the state (Jones 1964:178). This species inhabits areas with sandy soil and sparse vegetation, and we predicted that agricultural practices might have reduced habitat availability along parts of its easternmost range. Besides presenting data on current easternmost limits in the state, we also comment on habitat, reproduction, and taxonomic status of $D$. ordii in eastern Nebraska.

To examine whether populations of $D$. ordii still persist along its entire eastern boundary, we searched for evidence of Ord's kangaroo rat along this boundary, as well as in isolated areas of grasslands with sandy soils farther east of its published distributional range. Some locations reflected historical sites described in Jones

${ }^{1}$ Department of Biology, University of Nebraska at Kearney, Kearney, NE 68849

2Present address: Department of Fish, Wildlife, and Conservation Ecology, New Mexico State University, Las Cruces, NM 88003. E-mail: wrightgd@nmsu.edu 


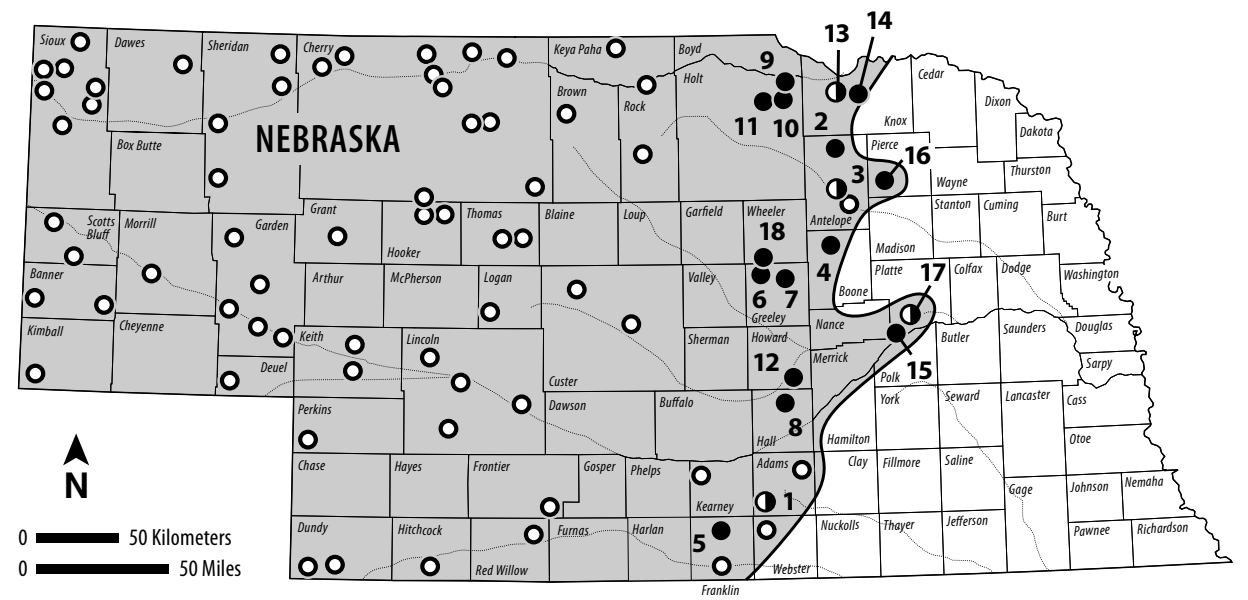

Fig. 1. Distribution of Ord's kangaroo rat (Dipodomys ordii) in Nebraska. Open and half-closed circles represent localities published in Jones (1964); half-closed circles also represent localities where we captured individuals at or near those reported by Jones (1964); and closed circles represent new records based on our trapping in 2008 . The shaded region represents the known distribution of $D$. ordii in Nebraska.

(1964), whereas many reflected areas with sandy soils along or near distributional limits for $D$. ordii in eastern Nebraska. Areas farther east of the known distribution were examined by searching for diagnostic trails, footprints, and escape holes, and at many of these sites, we trapped for small mammals even in absence of diagnostic sign of kangaroo rats. This trapping was associated with another project examining the distribution of 2 uncommon species of mice in eastern Nebraska that inhabit the same general habitat as $D$. ordii-the plains harvest mouse (Reithrodontomys montanus griseus) and the plains pocket mouse (Perognathus flavescens perniger; Geluso 2009). Some of these sites did not consist of sandy substrates.

From 6 June to 2 August 2008, we set Sherman live traps (H.B. Sherman, Tallahassee, FL) baited with mixed birdseed in roadside right-of-ways and state wildlife management areas, and on privately owned pastures in eastern Nebraska. Traps were set in late afternoon and checked the following morning. For all small mammals captured, we recorded age, sex, and reproductive status, and all animals were released at their respective capture sites. We kept a few individuals as voucher specimens, and these specimens, as well as corresponding field notes, were archived in the natural history collection in the Division of Zoology, University of Nebraska State Museum (UNSM), Lincoln, Nebraska, USA. Our observations on the number of embryos and lengths of testes correspond to only those individuals kept as voucher specimens. Coordinates of localities were determined with handheld GPS units using North American Datum 1983. We consulted the DeLorme Nebraska Atlas and Gazetteer (DeLorme Mapping Company 2000) to help us locate potential areas with sandy soils.

\section{Distribution and Habitat}

We observed 62 Ord's kangaroo rats in 13 counties along its easternmost limits in the state, including 8 counties without prior records (Fig. 1). One site in Pierce County (Fig. 1; Appendix) extends its distributional range a modest $22 \mathrm{~km}$ from the locality in Oakdale, Antelope County (Jones 1964). We documented D. ordii at or near most eastern sites reported by Jones (1964), but 2 exceptions included northeastern Adams County and northwestern Webster County. In both those areas, we did not observe sandy soils with sparse ground cover because much of those areas were agricultural fields. We did not search for D. ordii in southeastern Antelope County at Oakdale because of its proximity to records by Neligh (Appendix). We documented D. ordii from $35 \mathrm{~km}$ north of the Kansas border in Franklin County, Nebraska to within $5 \mathrm{~km}$ of South Dakota in Knox County, Nebraska (Fig. 1). Jones (1964) did not report captures in many counties in eastcentral Nebraska, but during our survey, we demonstrated that $D$. ordii occurs along its 
entire eastern border in the state where sandy soils exist (Fig. 1).

All of our individuals were captured on sandy soils, and common plants at capture sites included sage (Artemesia spp.), bluestem (Andropogon spp.), needle-and-thread (Stipa comata), yucca (Yucca glauca), ragweed (Ambrosia spp.), and cactus (Opuntia spp.). Across its entire distribution, habitat characteristics of $D$. ordii vary widely (Garrison and Best 1990), but Ord's kangaroo rats almost always are associated with friable, sandy soils (Jones 1964). Other common species of small mammals at our capture sites included the North American deer mouse (Peromyscus maniculatus) at $94 \%$ of sites and the plains pocket mouse (Perognathus flavescens) at $83 \%$ of sites. Of our captures, $76 \%$ of individuals $(n=47)$ were captured in roadside rightof-ways.

In Stanton County, we observed and trapped (448 trap-nights) rodents in a large alluvial deposit of sandy soil centered about $5.5 \mathrm{~km}$ southeast of Stanton; however, we did not capture $D$. ordii or observe diagnostic evidence (footprints, runways, and horizontally opening holes) in seemingly appropriate habitat. Plants in the area included big bluestem (Andropogon gerardii), needle-and-thread, sedges (Carex spp.), switchgrass (Panicum virgatum), ragweed, sage, horsetail (Equisetum arvense), flax (Phormium spp.), and cactus. During our survey, the range was grazed by cattle and supported open areas with sparse vegetation, including a number of blowouts. Without a prior survey of mammals, it is difficult to know whether kangaroo rats once existed and were extirpated at the site or whether individuals have never occupied this land because of geographical isolation or possibly physiological constraints.

\section{Reproduction}

Few details have been reported on the reproductive biology of $D$. ordii in Nebraska, but reproduction appears to occur from April to September (Jones 1964). We observed pregnant individuals on 5 July, 6 July, 9 July ( 2 embryos), 23 July (3 embryos), and 2 August (2 embryos). Previously, pregnant females have been reported May through September in the state, and mean number of embryos was $3.1(n=13)$ with a range of 2-5 (Jones 1964). We noted lactating females on 4 July, 9 July, and 2 August. We captured juveniles on $8,10,11,23,26$, and 31 July. The earliest reported capture of a juvenile in the state was on 3 May (Jones 1964). Scrotal males with enlarged testes were captured on 4 , 5 (12 × $5 \mathrm{~mm}$ in length), 6, 7, 8, 9, $25(15 \times 5$ $\mathrm{mm}$ and $12 \times 7 \mathrm{~mm})$, and $31(15 \times 7 \mathrm{~mm})$ July.

\section{Taxonomic status}

Two subspecies of Ord's kangaroo rat exist in Nebraska. Historically, the Platte River has been proposed as the dividing line between them$D$. o. luteolus to the north and D. o. richardsoni to the south. Jones (1964) admitted that this perception is one born more of convenience than fact and that a broad zone of intergradation is more likely. Based on our captures, we observed no consistently discernable difference in external characteristics from voucher specimens north and south of the Platte River.

\section{Conclusions}

Dipodomys ordii was extant in almost all counties with previous captures along its eastern limits in Nebraska as reported by Jones (1964). Based upon our study, kangaroo rats have experienced little change in distribution during recent decades in Nebraska. It can be assumed, however, that D. ordii has experienced some localized declines where sandy habitats have been converted to cropland. If the demand for corn or other crops increases in the future, other areas undoubtedly will be converted into agricultural lands. Despite those potential additional changes, Ord's kangaroo rat likely will persist where suitable habitat exists. Occurrence of individuals in roadside right-of-ways adjacent to agricultural lands supports the idea that populations can continue to persist, at least to some degree, in fragmented habitats. Our capture of D. ordii in Pierce County represents an extralimital record. Because of the paucity of mammalian records from Pierce County (see Jones 1964), we conclude that our records probably reflect a previously undocumented population and that the range enlargement is best described as a range extension and not a range expansion (Frey 2009).

Data presented herein were collected during a study funded by the Nebraska Game and Parks Commission to conduct surveys for the plains pocket mouse and plains harvest mouse in eastern Nebraska. We thank Mike Fritz (Nebraska Game and Parks Commission) for his assistance with grant-related matters; Angie Fox (University of Nebraska State Museum, University of Nebraska-Lincoln) for preparing Figure 1; and 
Trish Freeman and Tom Labedz (University of Nebraska State Museum, University of Nebraska-Lincoln) as well as Robert Timm (Natural History Museum, University of Kansas) for assistance with museum matters associated with this project. We also thank Ken Geluso for comments on an earlier version of this manuscript.

\section{Literature Cited}

Benedict, R.A., H.H. Genoways, and P.W. Freeman. 2000. Shifting distribution patterns of mammals in Nebraska. Transactions of the Nebraska Academy of Science 26:55-84.

Delorme Mapping Company. 2000. Nebraska atlas and gazetteer. 2nd edition. DeLorme Publishing Company, Yarmouth, ME.

FrEY, J.K. 2009. Distinguishing range expansions from previously undocumented populations using back- ground data from museum records. Diversity and Distributions 15:183-187.

Garrison, T.E., And T.L. Best. 1990. Dipodomys ordii. Mammalian Species 353:1-10.

Geluso, K. 2009. Survey of Reithrodontomys montanus griseus and Perognathus flavescens perniger in eastern Nebraska. Final Report to the Nebraska Game and Parks Commission, Lincoln, NE.

Hafner, D.J., And C.J. Shuster. 1996. Historical biogeography of western peripheral isolates of the least shrew, Cryptotis parva. Journal of Mammalogy 77: 536-545.

JoNEs, J.K., JR. 1964. Distribution and taxonomy of mammals of Nebraska. Publications of the Museum of Natural History, University of Kansas 16:1-356.

RAPOPORT, E.H. 1982. Areography: geographical strategies of species. Pergamon Press, Oxford.

Received 24 August 2009 Accepted 10 February 2010
APPENDIX. Localities of occurrence for Ord's kangaroo rat (Dipodomys ordii) in eastern Nebraska during our field efforts in 2008. Localities, dates of capture, number of trap nights, numbers of each sex captured, and specimen numbers (for animals retained as vouchers) are listed below. All voucher specimens were deposited in the zoological collection of the University of Nebraska State Museum (UNSM). Numbers preceding locations correspond to locations in Figure 1.

Adams Co.: (1) 2 mi S Holstein, $40^{\circ} 26.238^{\prime} \mathrm{N}, 98^{\circ} 38.823^{\prime} \mathrm{W}$ (26 July, 60 trap nights, 1 ㅎ, 2 우 우 [UNSM 2932]). Antelope Co.: (2) $5.2 \mathrm{mi}$ N Royal, $42^{\circ} 24.652^{\prime} \mathrm{N}, 98^{\circ} 02.247^{\prime} \mathrm{W}$

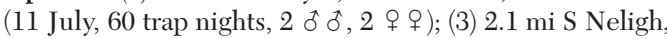
E side Hwy. $14,42^{\circ} 06.024^{\prime} \mathrm{N}, 98^{\circ} 02.812^{\prime} \mathrm{W}(10$ and 11 July, 220 trap nights, 3 ôे $\hat{\sigma}, 4$ $q$ q). Boone Co.: (4) Olson Nature Preserve, $2.8 \mathrm{mi} \mathrm{S}, 2.1 \mathrm{mi}$ W Petersburg, $41^{\circ} 47.840^{\prime} \mathrm{N}, 98^{\circ} 06.571^{\prime} \mathrm{W}$ (25 July, 40 trap nights, 1 ऽे [UNSM 29421]). Franklin Co.: (5) $0.5 \mathrm{mi} \mathrm{E} \mathrm{Hwy.} 10$ on Hwy. 4, $2.1 \mathrm{mi} \mathrm{W}, 1.8 \mathrm{mi} \mathrm{S}$ Upland, $40^{\circ} 17.545^{\prime} \mathrm{N}$, $98^{\circ} 56.492^{\prime} \mathrm{W}$ (23 July, 40 trap nights, 2 ㅎํㅇ, 1 우 [UNSM 29417]). Greeley Co.: (6) $4.6 \mathrm{mi} \mathrm{S}, 1 \mathrm{mi}$ E Ericson, $41^{\circ} 44.139^{\prime} \mathrm{N}, 98^{\circ} 39.780^{\prime} \mathrm{W}$ (2 August, 10 trap nights, 1 unknown sex, dead on road); (7) U.S. Hwy. 281, $1.4 \mathrm{mi} \mathrm{S}$ Hwy. $91,41^{\circ} 40.521^{\prime} \mathrm{N}, 98^{\circ} 32.395^{\prime} \mathrm{W}$ (25 July, 40 trap nights, 3 우 [UNSM 29424]). Hall Co.: (8) $6.7 \mathrm{mi} \mathrm{E}$ Cairo, $41^{\circ} 00.222^{\prime} \mathrm{N}, 98^{\circ} 28.810^{\prime} \mathrm{W}$ (25 July, 30 trap nights,

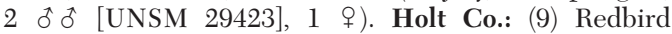
Wildlife Management Area, $42^{\circ} 45.372^{\prime} \mathrm{N}, 98^{\circ} 26.096^{\prime} \mathrm{W}(5$ and 6 July, 80 trap nights, 2 q q); (10) $18.7 \mathrm{mi} \mathrm{N}, 11.3 \mathrm{mi} \mathrm{E}$ O’Neill, $42^{\circ} 44.188^{\prime} \mathrm{N}, 98^{\circ} 26.543^{\prime} \mathrm{W}$ (6 July, 40 trap nights, 2 ऽิ ठิ); (11) $15 \mathrm{mi} \mathrm{N}, 5.5 \mathrm{mi}$ E O’Neill, $42^{\circ} 40.953^{\prime} \mathrm{N}$, $98^{\circ} 32.686^{\prime} \mathrm{W}$ (6 July, 40 trap nights, 1 o). Howard Co.: (12) $1 \mathrm{mi} \mathrm{S}, 5 \mathrm{mi}$ E Dannebrog, $41^{\circ} 06.338^{\prime} \mathrm{N}, 98^{\circ} 26.845^{\prime} \mathrm{W}$ (25 July, 36 trap nights, 3 oิ oิ [ UNSM 29419], 1 q). Knox Co.: (13) Hwy. 14, $1.4 \mathrm{mi} \mathrm{S}$ Hwy. 12, $42^{\circ} 43.838^{\prime} \mathrm{N}$, $98^{\circ} 02.918^{\prime} \mathrm{W}$ (4 and 5 July, 240 trap nights, 6 oิ के [UNSM 29361], 3 우 ㅇ); (14) $3 \mathrm{mi} \mathrm{S}, 4 \mathrm{mi} \mathrm{E}$ Niobrara, $42^{\circ} 42.624^{\prime} \mathrm{N}$, $97^{\circ} 57.279^{\prime} \mathrm{W}$ (31 July, 80 trap nights 1 ơ [UNSM 29328], 3 우 우). Merrick Co.: (15) 2.5 mi E, 3 mi N Silver Creek, $41^{\circ} 21.535^{\prime} \mathrm{N}, 97^{\circ} 37.050^{\prime} \mathrm{W}$ (8 July, 40 trap nights, 2 oे $\sigma^{\prime}$ [UNSM 29377], 1 ㅇ). Pierce Co.: (16) 9 mi N Meadow Grove (9 July, 160 trap nights, 2 ô $\delta, 4$ 우 [UNSM 29384]). Platte Co.: (17) $3.5 \mathrm{mi} \mathrm{E,} 6.5 \mathrm{mi} \mathrm{N}$ Silver Creek, $41^{\circ} 24.674^{\prime} \mathrm{N}, 97^{\circ} 35.958^{\prime} \mathrm{W}$ (7 July, 40 trap nights, 1 ऽ, 1 ㅇ [UNSM 29368]). Wheeler Co.: (18) $3 \mathrm{mi} \mathrm{S}, 1 \mathrm{mi}$ E Ericson, $41^{\circ} 44.598^{\prime} \mathrm{N}, 98^{\circ} 39.756^{\prime} \mathrm{W}$ (2 August, 20 trap nights, 1 ơ, 3 우 우 [UNSM 29333]). 